\title{
A FORAGE PLANT FROM \\ THE SOLANACEAE FAMILY
}

\author{
A Plant That When Young Is Very Similar to Tobacco and Much Appre- \\ ciated by Horses in Brazil
}

Benjamin Harris Hunicutt, M.S.A.

Director of the Lavras Agricultural School, Lavras, Brazil

$\mathrm{L}$

OOKING through the books on forage plants under common cultivation nowe are to be found belonging to the genus Solanum, nor to any other subdivisions of the Solanaceae family. The following notes on the Solanum bullatum, a promising forage plant of this family found wild in many parts of Brazil, are made from the standpoint of the agronomist and not so much of the botanist. Some time ago our attention was called to this plant by the articles in the Brazilian papers by the botanist, Dr. Alvaro A. da Silveira, whose work with little known plants suitable for forage purpose has been notable.

This plant has many common names in Brazil, differing in each state. In Minas it is called capoeira branca (white bush) and fructa de pomba (dove fruit). The first name is given on account of the whitish tinge of the leaves, especially as the plant gets older and grows into a small tree. The second name is given to it because the wild doves are very fond of the fruits; indeed, it is very hard to get seeds of the plant because the birds pick them before they are ripe. In São Paulo the common name is cuvetinga. which is probably the native or Indian name for it. In the State of Rio de Janeiro it is called fumeiro, or tobacco plant, because as a young plant it is very similar to the tobacco plant. It is also found in the State of Paraná and possibly in other states.

As a young plant it grows up as a bush with a number of stems coming up from the ground, but when older it is often found with only one trunk. Where it grows isolated it spreads quite widely (see Fig. 15), but when growing in very rich ground and along with other plants it reaches a height of 15 to 20 feet.

After a forest is cut off and the land turned over, among the first plants to appear is the Solanum bullatum, and its usefulness as a forage plant came to be noticed in that way. As soon as fresh land is cleared it is planted to corn. When the corn crop is harvested the cattle are turned in to eat off the stalks, and as this plant is generally to be found it was noticeable to what extent the cattle sought after it. When riding over our land it was often noticed that a horse would leave the road to try to get a nibble at this plant. One horse we owned could safely be ridden through a cornfield without his biting the corn, but it was difficult to get him past one of these plants without getting his mouth fatll: So far as we know no toxic effects have been observed from cattle or horses eating this plant. We were informed that. while it was not injurious to horses, it was poisonous to cattle. but this information is incorrect, for cattle are just as fond of it as horses and no ill effects are noticeable with either.

If it should be cultivated it would have to be planted close enough together in the rows to be utilized before it got too big or woody. It is perennial. but as a forage plant would have to be used as an annual. It will sprout from a cut trunk, but this would probably not prove to be of advantage agri- 


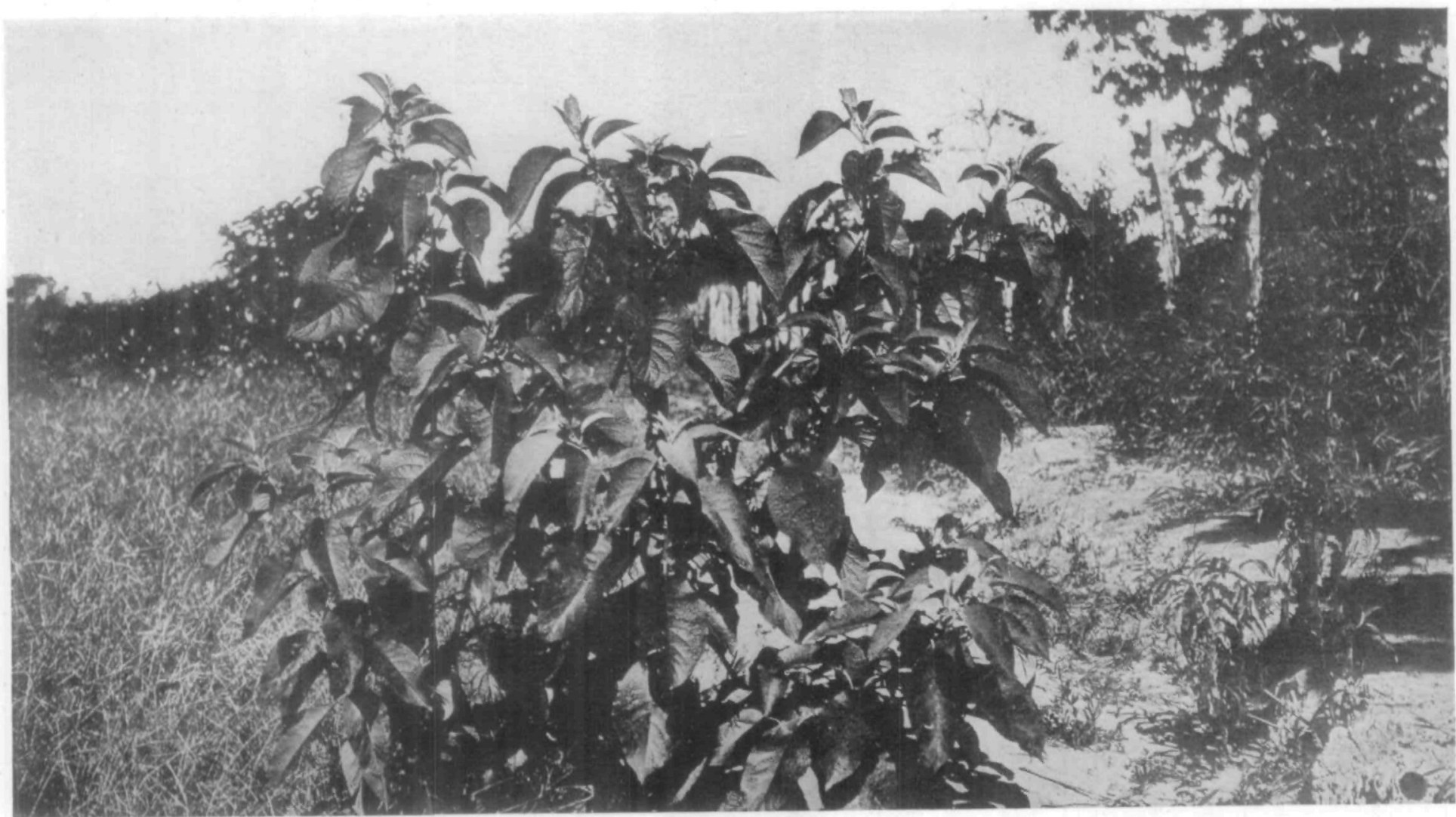

Brazilian forage plant

This plant when young resembles so much the tobacco plant that it is called "fumeiro" in the State of Rio de Janeiro. Horses and cattle are devoted to it, and it seems to agree with them. Chemical analysis shows an unusually high protein content. (Fig. 15 .) 
culturally. We have not been able to make fair tests of it as a cultivated plant, due to the difficulty of obtaining seed. Although it is common on our farm, it is very difficult to obtain even a small supply of seed. Several small quantities of seed have been sent to Hon. David Fairchild of the Foreign Seed and Plant Introduction Service of the Plant Industry Bureau. Possibly in the United States it will be easier to give it a trial.

As seen by the illustrations that accompany this article, this plant grows on hard, comparatively poor ground. The smaller, more bushy plant was found in the middle of the farm road on hard-packed ground. Nevertheless this plant is considered as one requiring fertile land, and is generally found on the better soils.

As to climate, Lavras is semi-tropical, our range of temperature being from $30^{\circ}$ to $90^{\circ} \mathrm{F}$., with an average of about $60^{\circ}$. But we saw this plant growing in the State of Paraná upon a mountain, where the cold is intense. How much frost it would stand we cannot say.

As to chemical analysis this plant reveals a very pleasant surprise. Its high protein content is very unusual. It is higher than that of most leguminous crops.

The analysis of the Secretary of Agriculture of Bello Horizonte is as follows :

Per cent

Moisture................... 10.468

Ash.......................... 9.980

Protein............................ 23.920

Fats................... 3.164
Cellulose. . . . . . . . . . . . . . . . . 26.780

Non-nitrogenous ext........... 25.688

Total

100.000

The analysis of the U. S. Department of Agriculture is as follows:

\begin{tabular}{|c|c|c|}
\hline & $\begin{array}{l}\text { Leaves. } \\
\text { per cent }\end{array}$ & $\begin{array}{c}\text { Branches } \\
\text { per cent }\end{array}$ \\
\hline 10 & 8.36 & 7.04 \\
\hline Eth & 2.29 & 0.59 \\
\hline Protein. & 20.88 & 14.06 \\
\hline Crude fiber. & 28.03 & 37.45 \\
\hline
\end{tabular}

This plant is highly appreciated by cattle and horses and would probably be a feasible crop for hay if it could be cut and prepared before getting too woody.

There is another of this genus, Solanum grandiflorum. or the frut of wolf, which has nearly $20 \%$ protein, which grows in much poorer land than the Solanum bullatum, and is eaten by the cattle in Brazil. This plant resembles a gigantic egg-plant. The tree has spines like the egg-plant and the fruits are similar also. The plant grows into a spreading tree about 8 to 10 feet high and will flourish on the poorest clay uplands. To us it does not appear to have much possibilities as an agricultural plant, but it seems to be worth more careful study and experiment to see what can be done with it. Lately we have had several inquiries about this plant from other parts of Brazil, and it is possible that soon something will be done with it in a practical way. We shall try and interest the government experiment stations in its cultivation and use.

\section{An Old Issue Especially Wanted}

Volume III, Nio. 1, the first quarterly issue of the American Breeders' Association (now the Journal of HeredITY), is especially desired. Anyone hav- ing a copy for sale will please communicate. Journal of Heredity, Box 472 , Eleventh Street Station, Washington, D. C. 